\title{
Transoperative refusion: a simple and safe method in emergency surgery
}

\section{Reinfusão transoperatória: um método simples e seguro na cirurgia de emergência}

\author{
luiz Carlos Buarque Gusmão, tCBC al ${ }^{1}$; Sérgio Henrique Chagas Valoes²; José da Silva leitão Neto 3
}

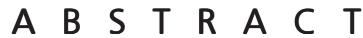

\begin{abstract}
The objective is to reinforce the importance of blood reinfusion as a cheap, safe and simple method, which can be used in small hospitals, especially those in which there is no blood bank. Moreover, even with the use of devices that perform the collection and filtration of blood, more recent studies show that the cost-benefit ratio is much better when autologous transfusion is compared with blood transfusions, even when there is injury to hollow viscera and blood contamination. It is known that the allogeneic blood transfusion carries a number of risks to patients, among them are the coagulation disorders mediated by excess enzymes in the conserved blood, and deficiency in clotting factors, mainly the Factor $V$, the proacelerin. Another factor would be the risk of contamination with still unknown pathogens or that are not investigated during screening for selection of donors, such as the West Nile Fever and Creutzfeldt-Jacob, better known as "Mad Cow" disease. Comparing both methods, we conclude that blood autotransfusion has numerous advantages over heterologous transfusion, even in large hospitals. We are not against blood transfusions, just do not agree that the patient's own blood is discarded without making sure there will be enough blood in stock to get him out of the hemorrhagic shock.
\end{abstract}

Key words: Blood. Blood Transfusion. Blood Transfusion, Autologous. Abdominal Injuries. Shock, Hemorrhagic.

\section{INTRODUCTION}

Internal bleeding from traumatic injuries in thoracic and abdominal cavities, as well as bleeding resulting from rupture of solid organs or mesenteric vessels, can lead to death if there is no adequate fluid resuscitation, and this passes obligatorily by blood replacement. Stopping the bleeding is not enough, one needs replace the lost volume.

Blood reinfusion is a method consisting in the reintroduction of blood lost by the patient at any bleeding, in the pre, per and post-operative, and accumulated in the thoracic or abdominal cavities. Its is collected by various means and immediately reintroduced into the patient's circulation '. It is, therefore, an autologous transfusion, which differentiates it from the other homologous transfusions ${ }^{2-5}$.

Currently, we highlight the main means of reinfusion usage: intraoperative, made with blood accumulated in serous cavities (hemoperitoneum and hemothorax); intraoperative, made with blood collected during surgical procedures; postoperative (using blood collected in surgical drains); of blood contained in the organs excised during surgery ${ }^{1,3,6}$. This method is used primarily in splenectomies, and should not be used on infected organs or in patients with malignancy ${ }^{1,7-10}$.

We must also remember the pre-deposit (programmed) autotransfusion, which consists of the prior collection of the patient's blood to be reinfused when necessary 1,3,4,11.

When comparing reinfusion with transfusion, there are obvious advantages of the former. Transfusion is actually an organ transplant, with all the disadvantages it can bring ${ }^{5}$. We know the various problems of the transmission of diseases, such as syphilis, Chagas disease and AIDS, to name a few $2,5,12$. Proponents of transfusion can say that the blood undergoes a series of tests that makes it exempt from being transfused with these diseases. However, we must remember that, in addition to the waiting time, the entailed costs are high. In the past, when AIDS was not known, several patients were contaminated during transfusions. Are we not transfusing some viruses that we do not know to exist, and in the future, will we not be regretting again, as we do today with AIDS? According to America's Blood Centers (ABC), there are currently other diseases that can be transmitted through blood transfusion, which are not properly investigated during screening for potential donors, such

1. Assistant, Professor, Federal University of Alagoas; 2. Hospital Pavilhão Pereira Filho da Irmandade Santa Casa de Misericórdia de Porto Alegre; 3. Cardiovascular Surgery, Santa Casa de Maceió. 
as West Nile Fever, parvovirus B19, babesiosis and Creutzfeldt-Jacob, its best-known variant being the "Mad Cow Disease" 13-15. Transfusion also uses a number of preservatives that can cause allergic reactions (asthma, laryngeal edema, urticaria, eczema, etc.), hypothermia and intoxications due to the use of sodium citrate and excess ammonia and potassium ${ }^{2,12}$. It also promotes changes in blood coagulability mediated by excess conserved enzymes in blood, and may cause hypercoagulability (by activating the pre-stage clotting) or incoagulability (by activation of plasma fibrinogen, creating an excessive fibrinolytic activity) ${ }^{2}$. There is also the deficiency of coagulation factors, especially factor $V$ - proacelerin - which leads to the perpetuation of bleeding in existing continuity solutions if one insists on blood transfusions ${ }^{2}$. We should also refer to individuals who do not accept blood transfusion of blood, or blood products from others, for religious reasons (Jehovah's Witnesses) ${ }^{16,17}$. Another factor of great importance would be the costs. In the United States about US $\$ 5$ billion was spent in the second half of 2008. IT is estimated that in the last decade about US\$ 1 billion was invested annually in new security measures, including generic HIV and Hepatitis B and C testing, among others ${ }^{13,14,18}$. By 2006, according to the Center for Management and Strategic Studies (CGEE) in Brazil, demand for blood products was met through imports, at an estimated five hundred million reais annual cost ${ }^{19}$.

In a retrospective analysis of 592 patients who underwent intraoperative autotransfusion, costs of conventional blood transfusion were compared with the ones of autologous transfusion as an adjunct therapy. The total cost of autotransfusion was US\$63,252.00. If the same amount of blood were to transfused with blood products, the cost would be around US\$114,523.00, a saving of around $45 \%{ }^{20,21}$. A study by Brown et al. ${ }^{21}$ in 2010 showed that autotransfusion had a cost of US $\$ 1,616$ per patient. Individuals undergoing only allogeneic transfusion had a cost of $\$ 2,584$ per patient ${ }^{21}$

Finally, there is no longer whole blood, the blood transfused in the operating room being the PRBC, thick and of slow infusion. And in reinfusion, which are the drawbacks? The autotransfusion is relatively free of complications. The exceptions would be the consumption of coagulation and platelet factors, contamination, sepsis, air embolism and hemolysis, occurring due to the handling of erythrocytes during the collection process in the cavity, leading, in some cases, to hemoglobinuria and hyperkalemia. The latter is, however, a very rare complication 2,8,22-24. Furthermore, reinfusion uses full blood (not fractioned), a method currently regaining advocates ${ }^{12,25}$.

In 2006, Bowley et al. ${ }^{26}$ performed a randomized study of 44 victims of penetrating abdominal trauma, in which 21 of these concurrently underwent allogeneic and autologous transfusion. After comparing with the control group of 23 patients who received only allogeneic blood, there were no discernible differences in the rates of postoperative infection and mortality 26 .

One of the main questions concerning the intraoperative transfusion in trauma is the risk of blood contamination. Horst et al. ${ }^{27}$ reviewed the use of reinfusion in a series of 154 trauma victims in 1992. Among 66 patients with intestinal lesions, 58 received contaminated blood and developed coagulopathy with a smaller amount of blood transfusions when compared with the group receiving uncontaminated blood. However, the 117 patients receiving less than 10 units of blood collected during operation had minimal changes in the coagulation parameters, regardless of the presence of intestinal lesions. According to the study, as for infection-related complications in patients both with and without intestinal lesions, the infection rate was higher in patients without bowel injury ${ }^{27}$. Bowley et al. ${ }^{26}$ found that $85 \%$ of patients in the group who underwent autologous transfusion had enteric contamination, and $38 \%$ had colonic injury. Of the blood samples from the reinfused group sent to culture, $90 \%$ were positive, but there was no correlation between the microbiological characteristics of reinfused blood and subsequent infectious complications. Moreover, there was no increase in septic mortality in patients receiving contaminated blood autotransfusion ${ }^{26}$

Another barrier to the use of such a procedure would be a worsening of coagulopathy in a patient with active bleeding. According to Brown et al. ${ }^{21}$, their studies suggested the opposite, stating that patients in the control group received more units of plasma than reinfused ones. The same can be observed in a the work of Bowley et al. ${ }^{26}$, in which there were no significant differences between the groups analyzed.

On balance, reinfusion won. We are not against transfusion, just do not agree that the patient's own blood be discarded without making sure there will be enough blood to get him out of hemorrhagic shock.

Blood reinfusion constitutes a very ancient practice. It was first performed in animals by Blundell in 1818. The first to perform it in a human was Highmore, in a case of postpartum hemorrhage. Sutugin, in 1868 , suggested the use of blood lost during surgical procedures. Miller, circa 1885, reinfused a patient undergoing an amputation $2,28,29$. Soon after, in 1886, Duncan ${ }^{30}$ also used reinfusion in an amputation, adding sodium phosphate to the blood to retard coagulation. In 1914, Thies made use of the method with great success in a case of bleeding ectopic pregnancy. During the First World War, Elmendorf first used autotransfusion on a hemothorax. His method was perfected by Symbas, who reinfused about 400 victims of traumatic hemothorax, without any noticeable complications ${ }^{31}$. Autologous transfusion was first used in abdominal trauma by Van Schaik in 1927. During World 
War II, autotransfusion was performed with an open suction and anticoagulation system through hemodilution or the use of citrate. Filtration was done by hand with cotton gauze 26,32

Blood reinfusion in Brazil was much used by surgeons, especially with the advent of an apparatus devised by Cordovil, in 1937, who performed the capture and filtration of blood directly from the peritoneal cavity. The procedure was, however, very laborious, because it required large vats and syringes to aspirate blood from the cavity through the apparatus. Successive injections were made in the vein of the patient as the syringes were filled, delaying the start of surgery. These problems contributed to the oblivion of the method, which did not withstand the rise of blood transfusions that were developing rapidly, offering a range of facilities, including appropriate and practical use bottles and equipment. In the 1960s, Bogossian published a series of papers on the development of a reinfusion technique, making it very practical and useful, especially in hard to reach places, with poor structure, being an alternative for patients who required immediate blood replacement ${ }^{2,3}$. It would also be handy in disasters and wars, when the consumption of blood products is huge, and the lack such components iis common.

In the Division of Trauma of the General Hospital of the State of Alagoas this method has been used successfully since the 80s. In the beginning, there was a great enthusiasm, and little by little, it fell into disuse, being applied only by a small group of surgeons.

We continue today as we did before, that is, harvesting the blood with a recipient or collecting it to a reservoir of chest drainage (Figure 1), filtering it manually with surgical packs (Figure 2), and placing it in an empty bottle of saline solution to reinfuse it with a catheter suitable for blood transfusion (Figure 3). For younger surgeons and anesthesiologists, such hardiness in the XXI century is harmful to blood cells, with which we agree. There is a series of kits in the market that, besides reducing the risk of contamination and hemolysis, facilitates reinfusion, ensuring the practicality of the method and allowing its better acceptance ${ }^{3,31,33-35}$.

Although the topic has already been widely reported, it was going into oblivion. We must remember that reinfusion is a simple and easy to handle method, which can be adapted to any small hospital, especially those that do not have blood banks. Moreover, it is a great option for large institutions, because it is safe and much cheaper than blood transfusions.

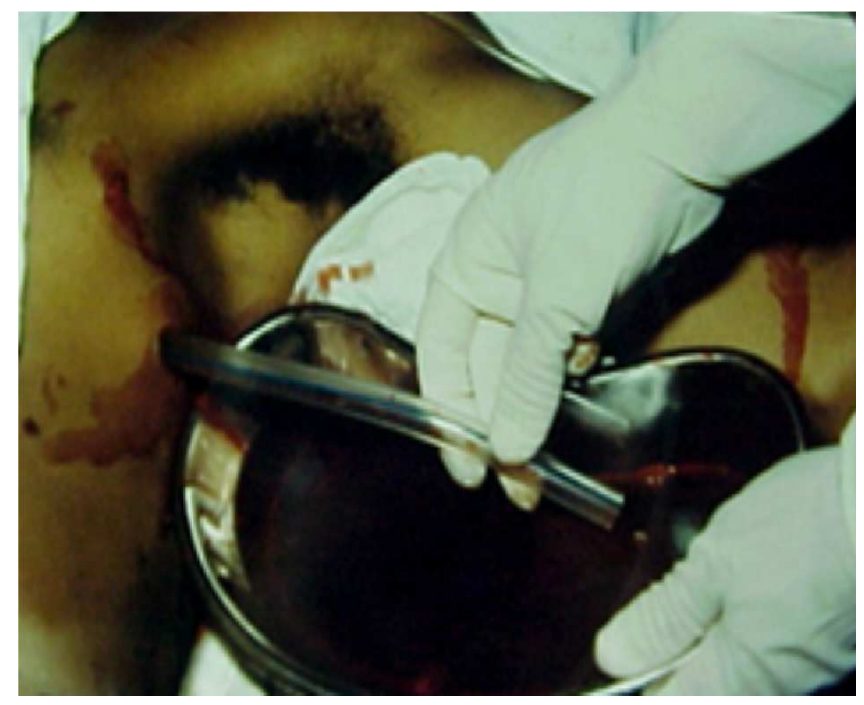

Figure 1 - Collection of blood from the pleural cavity.

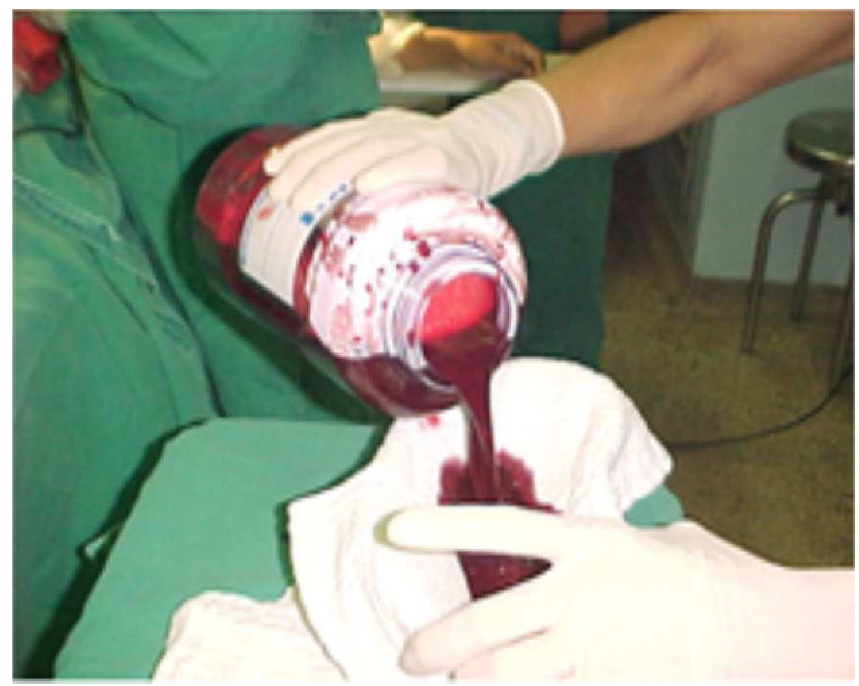

Figure 2 - Filtration of blood on surgical packs.

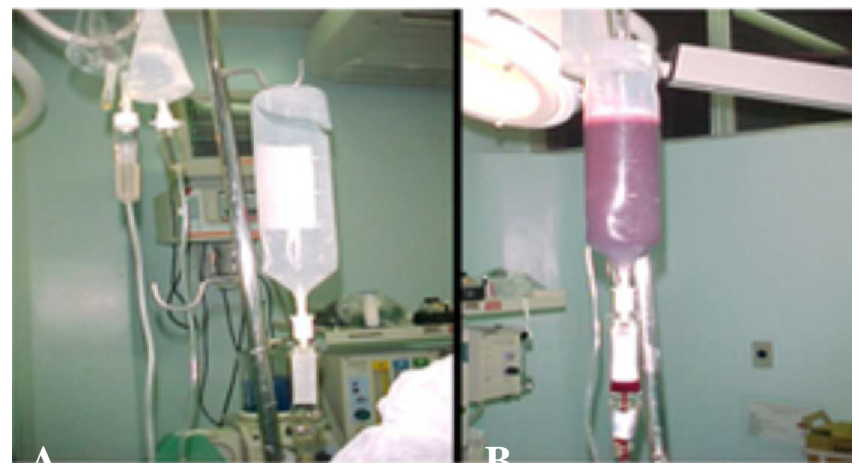

Figure 3 - A) empty solution bottle; B) bottle with filtered blood being reinfused. 


\title{
R E S U M O
}

\begin{abstract}
O objetivo deste trabalho é reforçar a importância da reinfusão sanguínea como um método barato, seguro e simples, e que pode ser utilizado em hospitais de pequeno porte, destacando aqueles que não dispõem de banco de sangue. Além disso, mesmo com a utilização de aparelhos que realizam a coleta e filtração do sangue, trabalhos mais recentes mostram que a relação custobenefício é bem melhor, comparando a transfusão autóloga com a transfusão de hemoderivados, mesmo quando há lesão de vísceras ocas e contaminação do sangue. Sabe-se que, atualmente, a transfusão de sangue alogênico acarreta uma série de riscos aos pacientes, dentre eles, estão os distúrbios de coagulação mediados pelo excesso de enzimas no sangue, conservada e deficiência nos fatores de coagulação; destacando o Fator $V$, a proacelerina. Outro fator seria o risco de contaminação com patógenos ainda desconhecidos ou que não são investigados durante a triagem para seleção de doadores, como por exemplo, a Febre do Nilo Ocidental e a Doença de Creutzfeldt-Jacob, mais conhecida como Doença da "Vaca Louca". Comparando ambos os métodos, concluímos que a autotransfusão sanguínea possui inúmeras vantagens em relação à transfusão heteróloga, mesmo em hospitais de grande porte. Não somos contra a transfusão de hemoderivados, só não concordamos que seja desprezado o sangue do próprio paciente, sem termos certeza de que vai chegar sangue em quantidade suficiente para tirá-lo do choque hemorrágico.
\end{abstract}

Descritores: Sangue. Transfusão de Sangue. Transfusão de Sangue Autóloga. Traumatismos Abdominais. Choque Hemorrágico.

\section{REFERENCES}

1. Bogossian L, Bogossian AT. Autotransfusão de pré-coleta imediata. Rev Col Bras Cir. 2008;35(4):259-63.

2. Bogossian L. Papel atual da reinfusão sanguínea. Folha Med. 1986;92(4):223-8

3. Adukauskienë D, $\square$ irvinskas E, Veikutienë A. Autologinio kraujo perpylima. Medicina (Kaunas) 2008;44(6):482-8.

4. Ridgeway S, Tai C, Alton P, Barnardo P, Harrison DJ. Pre-donated autologous blood transfusion in scoliosis surgery. J Bone Joint Surg Br. 2003:85(7):1032-6.

5. Keeling MM, Gray LA Jr, Brink MA, Hillerich VK, Balnd KI. Intraoperative autotransfusion: experience in 725 consecutive cases. Ann Surg. 1983;197(5):536-41.

6. Saarela E. Autotransfusion: a review. Ann Clin Res. 1981;13 Suppl 33:48-56

7. Walrond ER, Huston JE. Autotransfusion in splenic rupture. Lancet. 1965;286(7462):1134

8. Duncan SE, Klenaboff G, Rogers W. A clinical experience with intraoperative autotransfusion. Ann Surg.1974;180(3):296-304.

9. Alonso López R. La autotransfusión en la esplenectomía de urgencia. Rev cuba cir. 1984;23(2):114-26.

10. Witte CL, Esser MJ, Rappaport WD. Updating the management of salvageable splenic injury. Ann Surg. 1992;251(3):261-5.

11. Chen G, Zhang F, Gong M, Yan M. Effect of perioperative autologous versus allogeneic blood transfusion on the immune system in gastric cancer patients. J Zhejiang Univ Sci B. 2007;8(8):560-5

12. Nascimento Jr B, Scarpelini S, Rizoli S. Coagulopatia no trauma. Medicina (Ribeirão Preto). 2007;40(4):509-17.

13. MacPherson J. Blood costs and the market basket. Blood Counts 2009;1(1):1-2.

14. Blood Services: Cost, Reimbursement and billing. Blood Counts 2005:4(1):1-4.

15. Centers for Disease Control and Prevention (CDC). Investigation of blood transfusion recipients with West Nile virus infections MMWR Morb Mortal Wkly Rep. 2002;51(36):823.

16. Begliomini $H$, Begliomini BDS. Técnicas hemoterápicas em cirurgia renal percutânea em paciente testemunha de Jeová. Rev Col Bras Cir. 2005:32(6):350-2

17. Villarejo $P$, Padilla $D$, Cubo T, Marcote MA, Molina $M$, Menéndez $P$, et al. Cirugía y transfusión urgente en el paciente testigo de Jehová: revisión de las implicaciones médico-legales. Cir Esp. 2007:82(6):328-32.

18. Sugauchi F, Mizokami M, Orito E, Ohno T, Hayashi K, Kato T, et al. Molecular evolutionary analysis of the complete nucleotide sequence of hepatitis B virus (HBV) in a case of HBV infection acquired through a needlestick accident. Clin Infect Dis. 2000;31(5):1195-201.

19. Hemoderivados. Centro de Gestão e Estudos Estratégicos. Agência Nacional de Vigilância Sanitária. Rio de Janeiro, Março 2006.

20. Smith LA, Barker DE, Burns RP. Autotransfusion utilization in abdominal trauma. Am Surg. 1997;63(1):47-9.

21. Brown CV, Foulkrod KH, Sadler HT, Richards EK, Biggan DP, Czysz $C$, et al. Autologous blood transfusion during emergency trauma operations. Arch Surg. 2010;145(7):690-4.

22. Harris EM, D'Agostino J. Autotransfusion. In: King C, Henretig FM, editors. Textbook of pediatric emergency procedures. 2nd ed. Philadelphia: Lippincot; 2008. p.391-5.

23. Young GP, Purcell TB. Emergency autotransfusion. Ann Emerg Med. 1983;12(3):180-6.

24. Mattox KL. Autotransfusion in the emergency department. J Am Coll Emerg Phys. 1975;4(3):218-22

25. Holcomb JB, Jenkins $D$, Rhee $P$, Johannigman J, Mahoney $P$, Mehta $S$, et al. Damage control resuscitation: directly addressing the early coagulopathy of trauma. J Trauma. 2007;62(2):307-10.

26. Bowley DM, Barker P, Boffard KD. Intraoperative blood salvage in penetrating abdominal trauma: a randomised, controlled trial World J Surg. 2006;30(6):1074-80.

27. Horst HM, Dlugos S, Fath JJ, Sorensen VJ, Obeid FN, Bivins BA Coagulopathy and intraoperative blood salvage (IBS). J Trauma. 1992;32(5):646-52; discussion 652-3

28. Symbas PN, Levin JM, Ferrier FL, Sybers RG. A study on autotransfusion from hemotorax. South Med J. 1969;62(6):671 4

29. Pilcher LS. III. On transfusion and reinfusion of blood. Ann Surg. 1886;3(3):226-30.

30. Duncan J. On re-infusion of blood in primary and other amputations. Br Med J. 1886;1(1309):192-3.

31. Barriot P, Riou B, Viars P. Prehospital autotransfusion in lifethreatening hemothorax. Chest. 1988;93(3):522-6.

32. Hughes LG, Thomas DW, Wareham K, Jones JE, John A, Rees M Intra-operative blood salvage in abdominal trauma: a review of 5 years' experience. Anaesthesia. 2001;56(3):217-20. Erratum in: Anaesthesia. 2001;56(8):821.

33. Rosenblatt R, Dennis $P$, Draper LD. A new method for massive fluid resuscitation in the trauma patient. Anesth Analg. 1983;62(6):6136

34. Freischlag JA. Intraoperative blood salvage in vascular surgery worth the effort? Crit Care. 2004;8 Suppl 2:S53-6. 
35. Sturdee SW, Beard DJ, Nandhara G, Sonanis SV. Decreasing the blood transfusion rate in elective hip replacement surgery using an autologous drainage system. Ann R Coll Surg Engl. 2007;89(2):136-9.
Received on 15/10/2013

Accepted for publication 29/12/2013

Conflict of interest: none.

Source of funding: none.

Mailing address:

José da Silva Leitão Neto

E-mail: zleitao@hotmail.com 